\title{
Development of road infrastructure to support the development of village tourism
}

\author{
H. Siswanto*, Pranoto, C.P. Dewi \& B. Supriyanto \\ Universitas Negeri Malang, Malang, Indonesia
}

\begin{abstract}
Selorejo Village of Dau subdistrict in Malang Regency is a developing tourism village. One of the problems faced by this village is the lack of infrastructure to support tourism development. The entrances to the tourism spots are mostly dirt and narrow roads. The purpose of this paper was to develop planning for road infrastructure to support the development of tourism in and around the village. The method used was field surveys such as land survey, soil carrying capacity survey, and traffic surveys. The planning included pavement thickness and pavement width. The type of pavement chosen was block pavement. Block pavements were chosen because it allowed accommodation of aesthetic elements and are easy to implement and maintain.
\end{abstract}

Keywords: infrastructure, tourism village, carrying capacity

\section{INTRODUCTION}

Road infrastructure development is a very strategic choice for supporting tourism sector development activities. Selorejo Village of Dau District in Malang Regency has many tourism potentials, such as citrus picking tours, Bedengan camping grounds, waterfalls, and others. Bedengan Tourist attractions are mostly camping grounds, and they are to be developed to attract tourist visits. The route to such sites requires adequate road infrastructure for safe and comfortable passage. The road to such locations is made up of uneven and narrow dirt roads, putting tourists at unnecessary safety risks. Apart from still being dirt roads, the passages to Bedengan sites are narrow, limiting its access to smaller vehicles. To develop tourism in Bedengan, infrastructure improvements should be prioritized.

According to the World Economic Forum (2019), infrastructure is part of the main sub-index that supports tourism businesses and natural and cultural resources, tourism policies, and supporting environments. The infrastructure sub-index includes air transport infrastructure, roads and port infrastructure, and tourism services infrastructures. Several researchers have conveyed the relationships between infrastructure and tourism. The availability of infrastructure is a determinant in attracting tourist visits (Boopen 2006; Khadaroo \& Seetanah 2007; Brida et al. 2014; AlexOnyeocha et al. 2015; Jovanović \& Ilic 2016). Mandic et al. (2018) stated that tourist visit numbers are influenced by tourism infrastructure and facilities.

Infrastructure projects continue to be carried out by the Indonesian government to develop economic activities, including tourism. Tourism development has become part of the national priority programs (Moerwanto \& Junoasmono 2017). The tourism potential of Indonesia is large, but tourist visits have not been maximized. One way to increase tourist visits is by increasing the availability of road infrastructure.

The development of road infrastructure will increase the index of Indonesia's tourism competitiveness, where Indonesia's index level is currently ranked 40th out of 140 countries (World Economic Forum 2019). In ASEAN countries, Indonesia's tourism competitive index in 2019 is

\footnotetext{
*Corresponding author: henri.siswanto.ft@um.ac.id
} 
inferior to Thailand's 31, Malaysia's 29, and Singapore's 17. Indonesia's rank has improved significantly compared to 4 years ago, where Indonesia sat at $50^{\text {th }}$ place (Crotti \& Misrahi 2017). Indonesia's position rose 10 levels from rank 50 to 40 , which is the highest among ASEAN countries, followed by Thailand, which rose by 4 levels from rank 35 (Crotti \& Misrahi 2017) to 31, while Singapore fell 6 ranks from rank 11 to rank 17, and Malaysia fell 4 levels from rank 25 to rank 29. The rank increase in the competitive tourism index results from the continuous and comprehensive efforts of the Indonesian Government in developing the infrastructure sector. The development of road infrastructure was carried out thoroughly and included village areas that could attract higher tourist visits. Based on these conditions, it was necessary to plan adequate, comfortable, and safe road infrastructure for tourists.

\section{METHODS}

\subsection{Preliminary surveys}

In preliminary surveys, field visits and coordination with the head of the village of Selorejo were conducted. Next, digging information related to the existing tourism potential of the village was conducted. Then, learning the potential and the existing issue to use them as the research materials and the solution-finding. The team that conducts preliminary surveys was the whole community service implementation team.

\subsection{Field data collecting}

The Primary data collecting includes soil bearing capacity survey, traffic survey, and land measurement survey. Soil bearing capacity data is obtained by conducting DCPT (dutch cone penetration test) in the field. This tool is available in the road pavement laboratory of the Department of Civil Engineering UM. An analysis was done to determine the points of the area to be tested. The test is done on several points between the village office to Bedengan tourist location. The number of points that are chosen is 5 points, proportional to the field analysis of the visual conditions of the road. To conduct this soil bearing capacity survey, DPCT form is used. This DPCT survey needs four DCPT operators in addition to the community service team.

The traffic data were obtained by conducting a field survey on roads heading to Bedengan tourist location. Survey points are first determined to be able to retrieve data that is representative and to be able to conduct the survey technically and easily. The points that are chosen are one point at the village entrance and one point in the road heading to the orange picking tourist location. To conduct this survey, two people need to remain on the spot at each point during the survey. The survey is held from 6.00 in the morning to 17.00 in the afternoon. The land measurement survey was conducted to obtain cross-sectional data of the road of the community service location. The survey is held in two days. The operators come from the Survey and Mapping Laboratory of the Department of Civil Engineering, and the survey helpers are four university students.

\subsection{Data processing and data analysis}

Data processing was conducted on soil bearing capacity data, traffic data, and land measurement data. The soil bearing capacity data contained in the survey forms are processed by inserting them into tables and calculations to obtain the value of the soil bearing capacity in the form of the CBR (California Bearing Ratio) value. Meanwhile, the survey forms' traffic data were processed to obtain the average daily traffic (ADT).

\subsection{Pavement design}

Based on the survey results' primary data, pavement design for this tourist village road can be arranged. There are three possible types of pavement: flexible pavement, rigid pavement, and 
concrete block pavement (CBP). The last type of pavement, which is the concrete block pavement, is chosen for this planning. This is based on the consideration of what use this road will have, which is for tourism. Therefore, the element of beauty must be prioritized, in addition to the elements of strength, workability, cost, and ease of maintenance. The method used in this pavement design was the Indonesian method or the component analysis method. The CBP design concept is the same as the pavement asphalt design (Hein \& Smith 2014).

\section{RESULTS AND DISCUSSIONS}

In the preliminary survey, field visits were carried out to coordinate with village officials and determine the location for collecting technical data. The road conditions to the tourist location can be seen in Figure 1. The technical data that has been collected in this activity are soil bearing capacity data, traffic data, and land measurement data. Daily traffic data is presented in Table 1, while data on the soil bearing capacity is presented in Table 2 . The soil bearing capacity for this community service location is soil with moderate bearing capacity, specifically with an average CBR (California Bearing Ratio) value of $7.28 \%$.

The CBR founded allows all types of pavement to be applied. Three types of pavement can be applied, namely, flexible pavement, rigid pavement, and CBP. All types of pavement have their respective advantages and disadvantages. According to Gogoi (2019), choosing the type of pavement can be done based on, among others, the purpose of road services, construction implementation, maintenance, and availability of pavement material.

CBP has the advantage that it is easier to design, easy to procure, and easy to construct. These characteristics are suitable for road infrastructure in tourist areas. The usage of CBP is prevalent. According to Hettiarachchi and Mampearachchi (2016), CBP is in great demand due to its high availability in the market and its attractive design variations. In the last 10 years, CBP has been widely used in Europe because it is more durable against extreme weather. Also, it is more versatile compared to conventional asphalt pavement (Gunatilae \& Mampearachchi 2019). CBP is also used for local road, urban roads, (Di Mascio et al. 2019), pedestrian path, bike lane, the road in the housing area, and parking lots (Miccoli et al. 2014). In fact, CBP is also used in airport runways and ports (Pradena \& Houben 2016).

Table 1. The number of average daily traffic.

\begin{tabular}{lc}
\hline Vehicle Type & Volume (Vehicle per day) \\
\hline Motorcycle & 2397 \\
Passenger car & 489 \\
Pickup truck & 62 \\
Bus & 0 \\
Truck & 1 \\
\hline
\end{tabular}

Table 2. Data showing capacity of soil.

\begin{tabular}{lc}
\hline Location test & California Bearing Ratio (\%) \\
\hline 1 & 4.23 \\
2 & 6.96 \\
3 & 10.85 \\
4 & 6.94 \\
5 & 6.91 \\
\hline
\end{tabular}



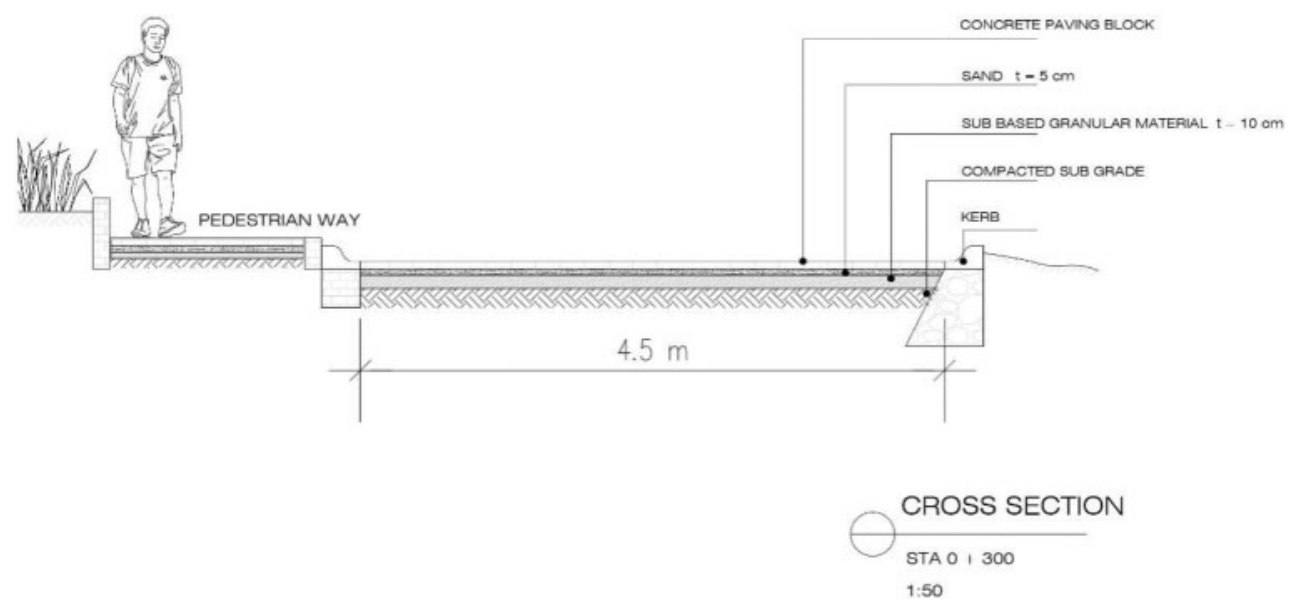

Figure 1. Cross section.

The results of this road infrastructure design are presented in Figure 1. The width of the existing road is $2.2 \mathrm{~m}$, which then widened twofold to $4.5 \mathrm{~m}$. The purpose of the widening is to accommodate traffic that is originally one-way into two-way. A further widening of more than the mentioned width is not possible due to its high construction cost, especially the costs of soil excavation and backfilling work. A pedestrian walkway is also added. The pedestrians are provided with a separate walkway to make the tourist village visitors feel more comfortable and safer in walking.

In line with the purpose of the road service, which is for tourism, the element of beauty must be prioritized and the elements of strength, workability, cost, and ease of maintenance.

\section{CONCLUSIONS}

The type of pavement chosen in this road infrastructure design is the concrete block pavement. This is based on the purpose of the road, which is for tourism. Therefore, the element of beauty must be prioritized, in addition to the elements of strength, workability, cost, and ease of maintenance.

\section{REFERENCES}

Alex-Onyeocha, O. 2015. The impact of road transportation infrastructure on tourism development in Nigeria, Pearl Journal of Management, Social Science and Humanities, 1(2), pp. 48-55.

Boopen, S. 2006. Transport capital as a determinant of tourism development: A time series approach, Tourismos, 1(1), pp. 55-73.

Brida, J. G., Deidda, M. and Pulina, M. 2014. Tourism and transport systems in mountain environments: Analysis of the economic efficiency of cableways in South Tyrol, Journal of Transport Geography. Elsevier Ltd, 36, pp. 1-11. doi: 10.1016/j.jtrangeo.2014.02.004.

Crotti, R. and Misrahi, T. 2017. Tourism Competitiveness - Paving the way for a more sustainable and inclusive future. Available at: http://www3.weforum.org/docs/WEF_TTCR_2017_web_0401.pdf.

Gogoi, R. 2019. Cost effectiveness of interlocking concrete block pavements for low volume traffic roads, International Journal of Engineering and Advanced Technology, 8(6), pp. 1239-1244. doi: 10.35940/ijeat.F8382.088619.

Gunatilake, D. and Mampearachchi, W. K. 2019. Finite element modelling approach to determine optimum dimensions for interlocking concrete blocks used for road paving, Road Materials and Pavement Design. Taylor \& Francis, 20(2), pp. 280-296. doi: 10.1080/14680629.2017.1385512. 
Hein, D. K. and Smith, D. R. 2014. Development of an asce standard for permeable interlocking concrete pavement, 2014 Transportation Association of Canada Conference and Exhibition: Past, Present, Future, ATC 2014, (October 2015).

Hettiarachchi, H. A. C. K. and Mampearachchi, W. K. 2016. New block design and laying parameters for interlocking concrete block pavements to improve human thermal comfort levels in urban spaces, International Journal of Sustainable Building Technology and Urban Development, 7(2), pp. 104-115. doi: 10.1080/2093761X.2016.1172278.

Jovanović, S. and Ilic, I. 2016. Infrastructure as important Determinant of Tourism Development in The Countries of Southeast Europe, 5(1), pp. 288-294.

Khadaroo, J. and Seetanah, B. 2007. Transport infrastructure and tourism development, Annals of Tourism Research, 34(4), pp. 1021-1032. doi: 10.1016/j.annals.2007.05.010.

Mandic, A., Mrnjavac, Ž. and Kordic, L. 2018. Tourism infrastructure, recreational facilities and tourism development, Tourism and Hospitality Management, 24(1), pp. 41-62. doi: 10.20867/thm.24.1.12.

Di Mascio, P., Moretti, L. and Capannolo, A. 2019. Concrete block pavements in urban and local roads: Analysis of stress-strain condition and proposal for a catalogue, Journal of Traffic and Transportation Engineering (English Edition). Elsevier Ltd, 6(6), pp. 557-566. doi: 10.1016/j.jtte.2018.06.003.

Miccoli, S., Finucci, F. and Murro, R. 2014. Criteria and procedures for regional environmental regeneration: A European strategic project, Applied Mechanics and Materials, 675-677(December), pp. 401-405. doi: 10.4028/www.scientific.net/AMM.675-677.401.

Moerwanto, A. S. and Junoasmono, T. 2017. Integrated Turism Insfrastructure development Strategic, HPJI Jounal, 3(2), pp. 67-78. doi: 10.26593/.v3i2.2735.\%p.

Pradena, M. and Houben, L. 2016. Functional criteria for sustainable design of urban pavements, Gradjevinar, 68(6), pp. 485-492. doi: 10.14256/JCE.1464.2015.

World Economic Forum. 2019. The Travel and Tourism Competitiveness Report 2019. 